\title{
Assessment of the Temporal and Spatial Variation of the Mercury Content of Lake Nokoué in Southern Benin Republic (West Africa)
}

\author{
Julien G. Adounkpe (iD, ${ }^{1,2}$ N. B. Nadia Azon $\mathbb{D}^{1},{ }^{1,3}$ Hermione W. Dégila, ${ }^{1,3}$ Peace Hounkpe, \\ and Robertson Amoussou ${ }^{3}$ \\ ${ }^{1}$ Laboratoire des Sciences et Techniques de l'Eau de l'Institut National de l'Eau, Université d'Abomey-Calavi, Benin \\ ${ }^{2}$ Laboratoire d'Ecologie Appliquée de la Faculté des Sciences Agronomiques, Université d'Abomey-Calavi, Benin \\ ${ }^{3}$ Laboratoire d'Etudes et de Surveillance Environnementale, Cotonou, Benin
}

Correspondence should be addressed to N. B. Nadia Azon; noubruna87@gmail.com

Received 28 April 2021; Revised 21 August 2021; Accepted 30 August 2021; Published 5 October 2021

Academic Editor: Karoly Nemeth

Copyright (c) 2021 Julien G. Adounkpe et al. This is an open access article distributed under the Creative Commons Attribution License, which permits unrestricted use, distribution, and reproduction in any medium, provided the original work is properly cited.

\begin{abstract}
Anthropogenic input of mercury into watersheds is becoming increasingly noticeable and is the cause of fishery products contamination. This had led to the Convention of Minamata signed and ratified by the vast majority of the countries in the world. Lake Nokoué in Benin Republic, the most fishery products provider in West Africa, is subject to mercury pollution. The health threat to both the benthic and the consumers of the fishery products from this lake has to be anticipated by precisely determining the dynamics of mercury contamination of the waters and sediments of Lake Nokoué, taking into account the anthropogenic contribution. Water and sediment samples were collected on 23 sites twice a month for four sampling campaigns. Parameters such as $\mathrm{pH}$, salinity, COD, and SS are evaluated in the water. The assessment of total mercury is conducted by cold vapor atomic absorption according to the US EPA 7473 method, using a direct mercury analyzer (DMA-80). On average, the mercury content in Lake Nokoué water is $0.43 \pm 0.57 \mu \mathrm{g} / \mathrm{kg}$. Its variation is linked not only to the seasonal variation but also to that of the suspended matter. South of the lake, the sediments are extremely polluted $(5 \leq$ Igeo) and present a risk of frequent effects for the benthic species present.
\end{abstract}

\section{Introduction}

Industrial, technological, and agricultural development is not without consequence on the environment [1]. Environmental pollutions, especially by heavy metals, are a threat to the aquatic ecosystems. Indeed, mercury pollution of surface water in Benin Republic is generally linked to agricultural activities and artisanal gold mining in northern Benin [2]. In the southern part of the country, the contamination of Lake Nokoue is strongly linked to the poor management of household and urban waste [3]. Lake Nokoué, being the largest lake in southern Benin, represents the base of the Ouémé river delta and communicates with watercourses such as the Ouémé river, the Djonou river, the Sô river, and the lagoon of Porto-Novo. The latter has been shown to be subject to mercury contamination [3].
Lake Nokoué hosts and is surrounded by several cities that use various types of batteries as their major sources of electricity. Those batteries are potential sources of mercury [1]. The banks of the lake are under the influence of large metropoles such as Cotonou, the economic capital of the country, and Abomey-Calavi, the dormitory city, where sanitation is of great concerns (Figures 1 and 2 ). Previous studies showed the presence of mercury in the flesh of fish species such as fish, shrimp, and oysters [4]. Even though if the current levels of mercury content seem not alarming, it should be noted that the bioamplifying power of the metal in the trophic network can rapidly degrade the current situation [5].

Additionally, mercury in the aquatic environment not only intoxicates the water body living organisms but can also be stored in the sediments where the bottom dwellers are 


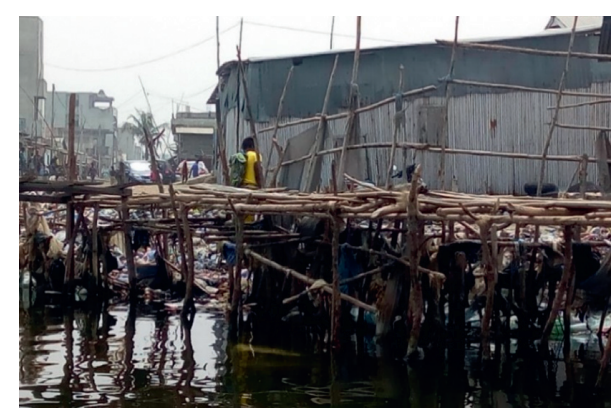

Figure 1: Human settlement on the Lake Nokoué bank at YénawaCotonou (southeast of Lake Nokoué).

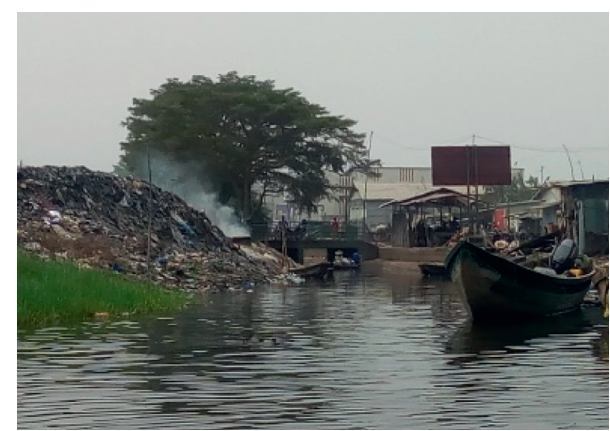

Figure 2: Wild dumpster at Vossa-Cotonou (southwest of Lake Nokoué).

exposed to its toxic effects. Later on, given certain atmospheric conditions, it can re-surface and get into the water body [6]. It is therefore of upmost importance to anticipate mercury pollution of the aquatic system in order to prevent its harmful consequences on aquatic fauna. This requires a quantification of mercury not only in the water but also and especially in the sediment for necessarily actions. The current study investigates the anthropogenic influence on the mercury pollution of the waters and sediments of Lake Nokoué, while taking into account the effect of seasonal variation.

\section{Material and Method}

2.1. Sampling. From July 2019 to January 2020, 23 sampling points were monitored bimonthly on the tributaries of Lake Nokoué, thus taking into account all the climatic seasons of the year. Thus, the junctions between Lake Nokoué and the other watercourses such as the Ouémé river, the Djonou river, the Sô river, and the Porto-Novo lagoon were sampled. Also the lake towns and the discharge points of the rainwater collection pipes were collected (Table 1).

Water samples were taken from a depth of $0.5 \mathrm{~m}$ below the water surface and transferred to $125 \mathrm{~mL}$ pretreated bottles. The bottles were protected from the air by putting them in plastic bags with zip, thus avoiding any atmospheric contamination of the samples stored with concentrated nitric acid (37\%) at 5\% v/v.
Sediment samples were also collected from each of the 23 sites using a Van Veen grab at a depth between 0 and $5 \mathrm{~cm}$. All the samples were labeled and stored at a temperature between 2 and $8^{\circ} \mathrm{C}$ according to the standard NF EN ISO 5667-15, 2009.

\subsection{Chemical Analysis}

2.2.1. Physicochemical Parameters. The water samples were subjected to measurements such as $\mathrm{pH}$, salinity, conductivity in situ, and chemical oxygen demand (COD) and suspended solids (SS) in the laboratory. The parameters were measured in situ using a YSI multiparameter water quality meter from Fisher Scientific.

The COD was evaluated by titrimetry in accordance with the AFNOR T90-101 standard, and the SS were assessed following the AFNOR T90-105 standard.

2.2.2. Determination of Mercury Content. Total mercury content was determined in both water and sediment samples using a direct mercury analyzer (DMA-80). The method has been extensively described elsewhere $[1,7,8]$. In short, this mercury analyzer has the particularity to directly assay the metal without any chemical pretreatment. It has a system of three ovens, the first of which is used for drying and decomposing the sample. The second furnace serves as a catalytic chamber, while the last furnace has a gold trap that captures the mercury released from the sample for a spectrometric reading. Thus, mercury is detected by cold vapor atomic absorption spectrometry by using the 7473 USPEA method.

2.3. Evaluation of Sediment Quality. The ecological quality evaluation of the sediment samples was made through four factors $[9,10]$. The assessment of the geo-accumulation index (Igeo) is conducted according to the following formula:

$$
\text { Igeo }=\log 2\left(\frac{C m}{1,5 * C f g}\right),
$$

where $\mathrm{Cm}$ corresponds to the measured mercury concentration, $C f g$ corresponds to the geological concentration of mercury, and 1.5 is the correction factor for the geochemical background $[11,12]$.

Taking into account the mercury ratio in the sediment without considering the heterogeneity of the sediments is appreciated by the contamination factor [13], and the formula is

$$
\mathrm{FC}=\left(\frac{C m}{C f g}\right) .
$$

Finally, the threshold effect level (TEL) and the probable effect level (PEL) made it possible to assess the ecological quality of the sediments studied [14]. 
TABLE 1: Geographical coordinates of the sampled sites.

\begin{tabular}{lccc}
\hline Sampled areas & Code & X coordinate & Y coordinate \\
\hline Tributary of the Sô & NA & 2.3878816667 & 6.4770066667 \\
Tributary of the Sô & NB' & 2.3911616667 & 6.4678444444 \\
Tributary of the Sô & NB & 2.3886111111 & 6.4624933333 \\
Tributary of the Sô & NC & 2.4087833333 & 6.4671116667 \\
Tributary of the Sô & ND & 2.4165116667 & 6.4745083333 \\
Tributary of the Sô & NE & 2.421208333 & 6.484571667 \\
Tributary of the Sô & NF & 2.4294266667 & 6.5094333333 \\
Affluent of Aguégués & NG & 2.5284233333 & 6.4524833333 \\
Tributary to the lagoon of Porto-Novo & NH & 2.5444433333 & 6.4373983333 \\
Periphery & NI & 2.5430066667 & 6.4208255555 \\
Middle & NJ & 2.5074966667 & 6.4348183333 \\
Middle & NK & 2.4464716667 & 6.4442216667 \\
Middle & NL & 2.3816066667 & 6.4311633333 \\
Pipe rejection & NM & 2.41584333333 & 6.3891211111 \\
Tributary of the Djonou & NM' & 2.3534783333 & 6.4006111111 \\
Enter the Cotonou channel & NN' & 2.3534783333 & 6.4006111111 \\
Pipe rejection & NP & 2.4359583333 & 6.3897016667 \\
Pipe rejection & NR & 2.4373444444 & 6.3886255555 \\
Pipe rejection & NS & 2.4432916667 & 6.3970316667 \\
Pipe rejection & NS' & 2.4471766667 & 6.3957355555 \\
Pipe rejection & NT & 2.4582999999 & 6.3938366667 \\
Pipe rejection & NU & 2.4623555555 & 6.3927016667 \\
Pipe rejection & NX & 2.4658155555 & 6.3919355555 \\
\hline
\end{tabular}

2.4. Statistical Analysis of Data. Following the descriptive analysis which is carried out on all the data, the distribution of mercury in the water and sediment matrices is assessed by the box-whisker plot. Analysis of variances is performed to assess the effect of sampling areas and other parameters on the variation in mercury content.

\section{Results and Discussion}

3.1. Lake Nokoué Water Physicochemical Parameters of Distribution. Table 2 presents the descriptive statistics of all the physicochemical parameters measured in the water of Lake Nokoué. The water temperature varies from $26.40^{\circ} \mathrm{C}$ to $31.70^{\circ} \mathrm{C}$ with an average of $29.37^{\circ} \mathrm{C}$. This temperature amplitude is included in the range of temperature variation (24 to $35^{\circ} \mathrm{C}$ ) that favors good fish growth in lagoon waters [15]. It is therefore understandable that Lake Nokoué be a very good fishery products sustainer.

The $\mathrm{pH}$ of the water in Lake Nokoué varies between 3.90 and 11.18 with an average of 7.10 (Table 2). This average value $(\mathrm{pH}=7.2)$ corroborates observations by Djihouessi in 2018 related the waters of Lake Nokoue for the same period of the year [16]. The low pH value observed at Lake Nokoué could be due to occasional organic pollution, linked to domestic and industrial discharges or the effect of palm tree leaves and other plants used as fish habitat, the so-called acadjas [17]. In addition, the lowest $\mathrm{pH}$ values recorded during the month of September corresponding to the short rainy season are 4.96 and 3.9, respectively, at the Djonou river tributary (NM) and the point discharge of the rainwater draining pipe at Vossa $\left(\mathrm{NM}^{\prime}\right)$. This may be related to the nature of the ions dragged by the tributary or the pipeline into the lake (Figure 3). The $\mathrm{pH}$ values in particular during the month of January, period of water recession and dry season where the highest $\mathrm{pH}$ values are recorded, could mean that the seasonal variation or the water height influences the acidic or basic character of the water of Lake Nokoué. This same observation is made by Buhungu et al. in 2018 about the Kinyankonge fishpond in Burundi [18].

The conductivity of the water in Lake Nokoué water varies greatly with a minimum of $1 \mu \mathrm{s} / \mathrm{cm}$, a maximum of $32723 \mu \mathrm{s} / \mathrm{cm}$, and an average of $4992.34 \mu \mathrm{s} / \mathrm{cm}$ (Table 2 ). This average value greatly exceeds the limit value of $1000 \mu \mathrm{s} / \mathrm{cm}$ set by the WHO for natural waters. However, the average value corroborates with the results found by Avmadi in 2019 $(3482 \mu \mathrm{s} / \mathrm{cm})$ in Lake Togo. The high conductivity values obtained in the waters of Lake Nokoué could be explained by the variation of the tides on one hand and by the influence of human activities on the other hand. Indeed, the measurement of the conductivity of a water body, which is in itself the evaluation of the degree of ionization of this medium, depends essentially on the presence and the concentration of the various ions in the water [19]. However, given that Lake Nokoue is connected to the Atlantic Ocean via the channel of Cotonou (see map), the highly ionized seawater income greatly impacts the conductivity of the lake.

The salinity of Lake Nokoué varies from $0 \mathrm{ppt}$ to 18.13 ppt with an average of $2.87 \mathrm{ppt}$ in Lake Nokoué (Table 2). These results corroborate with the ones observed (0 ppt to $16.2 \mathrm{ppt}$ ) in Lake Nokoué by Djihouessi in 2018. Finally, the chemical oxygen demand varies between $91.43 \mathrm{mg} / \mathrm{L}$ and $3072 \mathrm{mg} / \mathrm{L}$ with an average of $337.96 \mathrm{mg} / \mathrm{L}$ in the waters of Lake Nokoué. These values are much higher than those obtained in the Chari River [20].

The highest values of conductivity and salinity are observed during the months of July and January (Figures 4 and 5). These 
TABLE 2: Statistical data of the physicochemical parameters of water.

\begin{tabular}{|c|c|c|c|c|c|c|c|}
\hline Parameters & $n$ & Mean & Median & Min & Max & $\mathrm{Sd}$ & se \\
\hline Temp $\left({ }^{\circ} \mathrm{C}\right)$ & 276 & 29.37 & 29.50 & 26.40 & 31.70 & 1.09 & 0.07 \\
\hline $\mathrm{pH}$ & 276 & 7.10 & 7.13 & 3.90 & 11.18 & 1.02 & 0.06 \\
\hline Cond $(\mu \mathrm{s} / \mathrm{cm})$ & 276 & 4992.34 & 499.45 & 1.00 & 32723.00 & 9080.87 & 546.60 \\
\hline Sal (ppt) & 276 & 2.87 & 0.24 & 0.00 & 18.13 & 4.93 & 0.30 \\
\hline $\operatorname{COD}(\mathrm{mg} / \mathrm{L})$ & 276 & 337.96 & 182.86 & 91.43 & 3072.00 & 468.58 & 28.20 \\
\hline $\operatorname{MES}(\mathrm{mg} / \mathrm{L})$ & 276 & 0.08 & 0.03 & 0.00 & 1.48 & 0.20 & 0.01 \\
\hline Hg-Suf $(\mu \mathrm{g} / \mathrm{L})$ & 276 & 0.43 & 0.24 & 0.02 & 4.93 & 0.57 & 0.03 \\
\hline $\mathrm{Hg}-\mathrm{Sed}(\mu \mathrm{g} / \mathrm{Kg})$ & 276 & 7139.02 & 218.42 & 21.74 & 80976.68 & 14449.48 & 869.76 \\
\hline
\end{tabular}

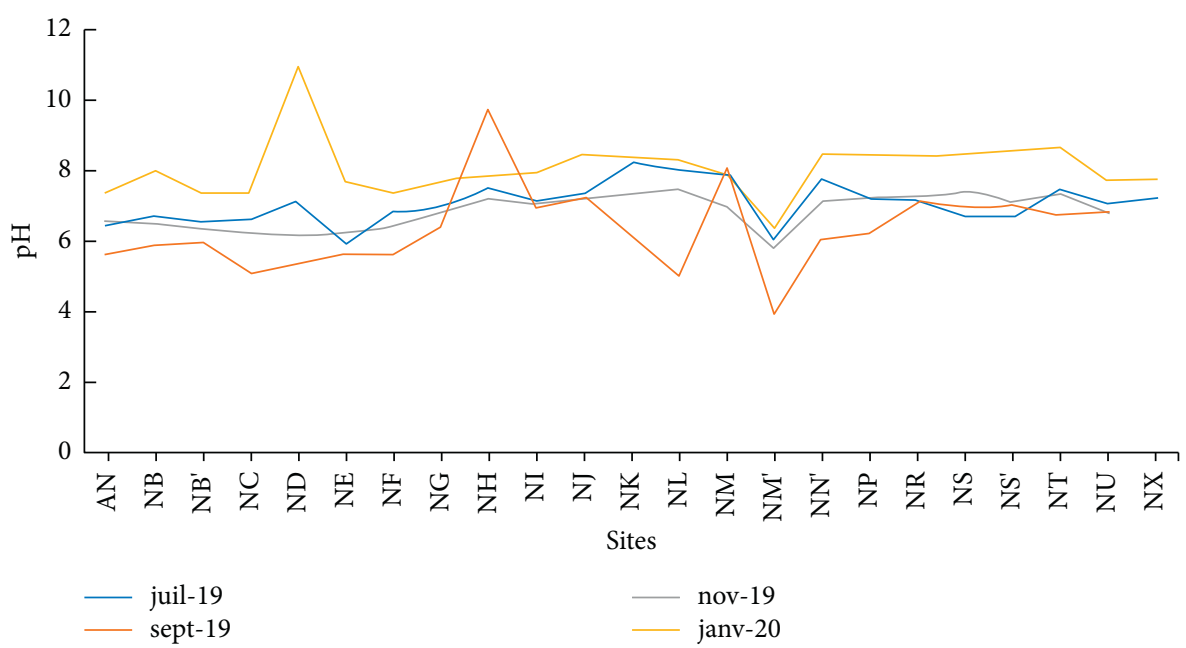

FIgURE 3: Temporal variation of the $\mathrm{pH}$ in the water.

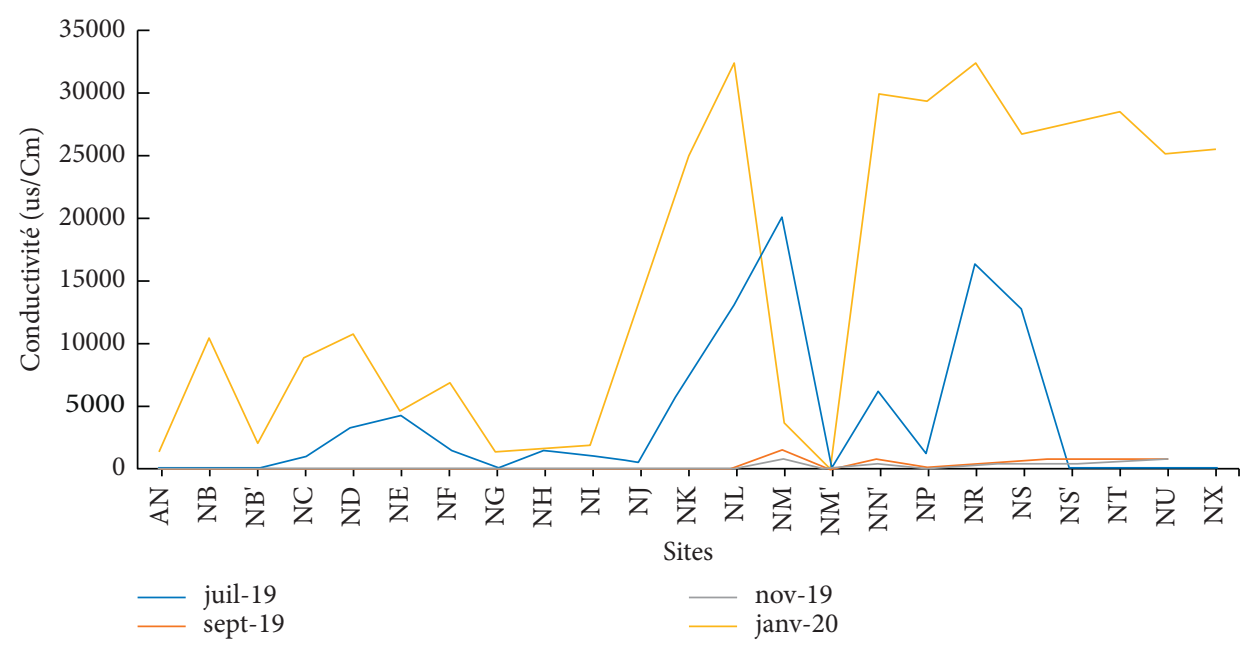

Figure 4: Temporal variation of the conductivity of Lake Nokoué.

periods correspond, respectively, to the great rainy season and the great dry season. Indeed, during the rainy period, the runoff water, by washing off the soils, drains ionic charges into the lake. Hence, the high values observed during July with peaks of $20382.57 \mu \mathrm{s} / \mathrm{cm}$ and $16403.57 \mu \mathrm{s} / \mathrm{cm}$ for conductivity and peaks of $10.67 \mathrm{ppt}$ and $8.80 \mathrm{ppt}$ for salinity, respectively, at the discharge points of the rainwater pipes at Vossa (NM) and Adogléta (NR) are logical. During the periods of high-water level (August-September), the conductivity recorded is less than $100 \mu \mathrm{s} / \mathrm{cm}$ and the salinity less than $1 \mathrm{ppt}$ at all sampled sites. When the water recedes by January, the conductivity and salinity experience spectacular variations with conductivities over $20,000 \mu \mathrm{s} / \mathrm{cm}$ and salinities over $10 \mathrm{ppt}$ in the downstream area of the lake (Ladji, Vasso, Adogléta, Agbato, and Yénawa).

3.2. Mercury Content Variation in Water and Sediment. The mercury content in the waters of Lake Nokoué varies from $0.02 \mu \mathrm{g} / \mathrm{kg}$ to $4.93 \mu \mathrm{g} / \mathrm{kg}$ with an average of 


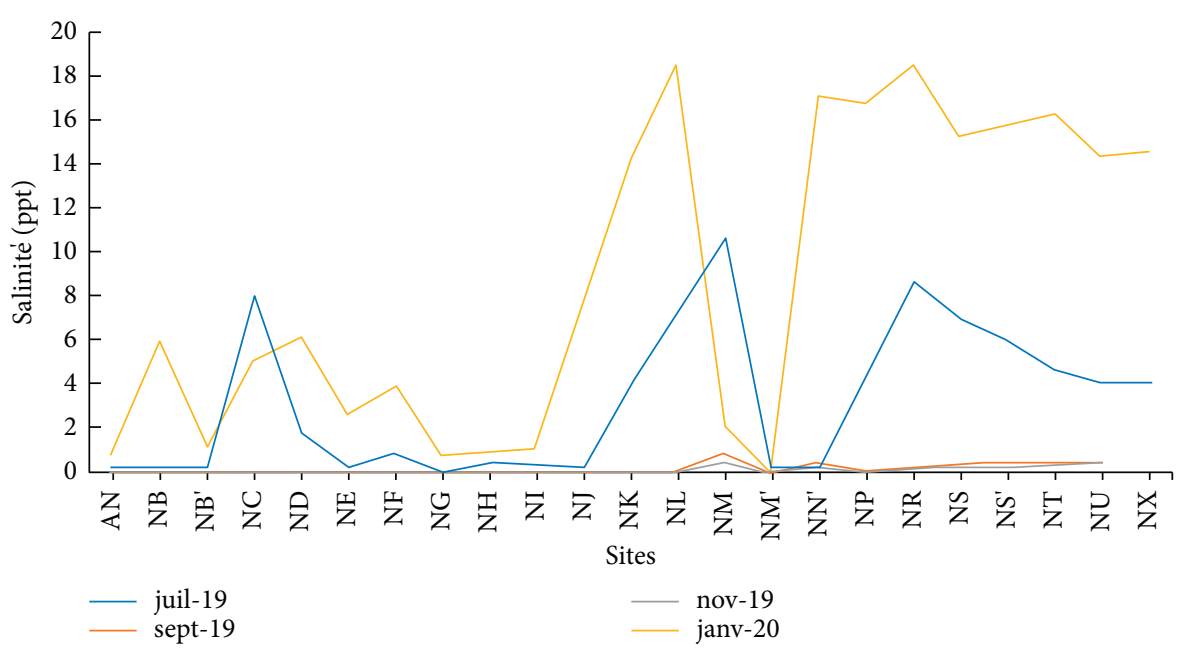

Figure 5: Temporal variation of the salinity in the water of Lake Nokoué.

$0.43 \pm 0.57 \mu \mathrm{g} / \mathrm{kg}$ (Table 3). Although being remarkably present in all the sampling sites, the quantity of mercury during the month of July remains below $2 \mu \mathrm{g} / \mathrm{kg}$, the limit value for mercury in surface water according to Rodier et al. in 2009 [21] (Figure 6). However, the mercury concentrations in the tributaries of the Sô river (NF), the Porto-Novo lagoon $(\mathrm{NH})$, the Ouémé river $(\mathrm{NG})$, urban wastewater discharge pipes (NT, NP) and (NU), the Cotonou channel $\left(\mathrm{NN}^{\prime}\right)$, and certain specific sites (NJ, NB) for the same month have an average concentration that exceeds $1 \mu \mathrm{g} / \mathrm{L}$ that is obtained in the waters of the Konkouré river estuary [22]. $1 \mu \mathrm{g} / \mathrm{L}$ also represents the limit value for mercury set by the WHO. This high mercury content may be due to the leaching from dumpsters alongside the lake. The low mercury contents $(<1 \mu \mathrm{g} / \mathrm{L})$ are observed in September, November, and December where there is no much of leaching. The exceptional peak of $3.81 \mu \mathrm{g} / \mathrm{L}$ of mercury obtained during the month of September in Ganvié (NC) can be explained by a point contamination, which would certainly be linked to the current activities of the populations of the city.

The mercury content in the sediments collected from the same sites as the water samples from July to January varies from $21.74 \mu \mathrm{g} / \mathrm{kg}$ to $80976.68 \mu \mathrm{g} / \mathrm{kg}$ with an average of $7139.02 \mu \mathrm{g} / \mathrm{kg}$ (Figure 7). The highest mercury content in the sediment of Lake Nokoué is obtained at the tributary's outlets, at the discharge points of the pipes, and at the point of the lake's outlet into the channel of Cotonou. Each of these sediments has concentrations greater than $0.5 \mathrm{mg} / \mathrm{kg}$ of mercury, limit values according to the OSPAR standard $[23,24]$. This is an additional proof that the probable sources of mercury contamination of Lake Nokoué are households, urban discharges, and wild dumpsters (NC, NT, NM, NS, NE, NF, etc.).

It should be noted that the concentration of mercury presents a better distribution within the water matrix at the level of the tributaries and within the body of the lake itself (Figure 8(a)). However, at the pipe's outlet and at the inlet of the channel of Cotonou, the behavior of the metal can be linked to a possible swing of the metal contained in the water column toward the sedimentary medium. The high mercury contents are obtained at the level of the discharge points of the rainwater collection pipes into the lake (Figure 8(b)). Even if mercury does not seem to present a better distribution in the sedimentary environment at those areas, the 4th quartile exhibiting concentrations ranging from 25,000 to $60,000 \mu \mathrm{g} / \mathrm{kg}$ and the $3 \mathrm{rd}$ quartile observations vary between approximately $8,000 \mu \mathrm{g} / \mathrm{kg}$ and $25000 \mu \mathrm{g} / \mathrm{kg}$ give the proof of anthropogenic pollution. This would be due not only to the leaching from the soil by runoff water but also to the household garbage often dumped in the water collectors by the population and to the presence of the refuse installed directly on the banks. Thus, it emerges that the mercurial concentration of the sedimentary environment of Lake Nokoue is strongly influenced by the nonmanagement of urban waste from the city of Cotonou.

\subsection{Influence of the Physicochemical Parameters of Water on} the Variation of Mercury. The ANOVA results (Table 4) reveal a significant difference between the campaign periods $(p<0.001)$. The variation of mercury in lake waters is strongly dependent on suspended solids with a probability less than 0.05 . The effect of categorical interactions shows that the period of the campaigns influences the variation of mercury in water. Thus, the seasons or periods of flooding and falling considerably influence the mercury content in the waters of Nokoué. This confirms that during the rainy period, the water inflow into the lake contributes to a mercury supply in the body of water. In short, the season and the height of the water influence the mercury content in the water, which in itself remains dependent on suspended matter present in the medium.

In addition, the sediment sampling depth shows a significant difference $(p<0.001)$ with regard to the mercury content in the sedimentary environment. The mercury content does not seem to be influenced by the parameters of the water in any way (Table 5). However, the results of the effects of the interactions of the categorical variables reveal a level of significance at the threshold of $p<0.05$. This confirms the influence of the sampling periods on the variation 
TABLE 3: Statistical data of the mercury concentration in water and sediment.

\begin{tabular}{|c|c|c|c|c|c|c|c|}
\hline Parameters & $n$ & Mean & Median & $\min$ & Max & $\mathrm{Sd}$ & se \\
\hline Hg-water $(\mu \mathrm{g} / \mathrm{L})$ & 276 & 0.43 & 0.23 & 0.02 & 4.93 & 0.57 & 0.03 \\
\hline Hg-Sed $(\mu \mathrm{g} / \mathrm{kg})$ & 276 & 7139.02 & 218.42 & 21.74 & 80976.68 & 14449.48 & 869.76 \\
\hline
\end{tabular}

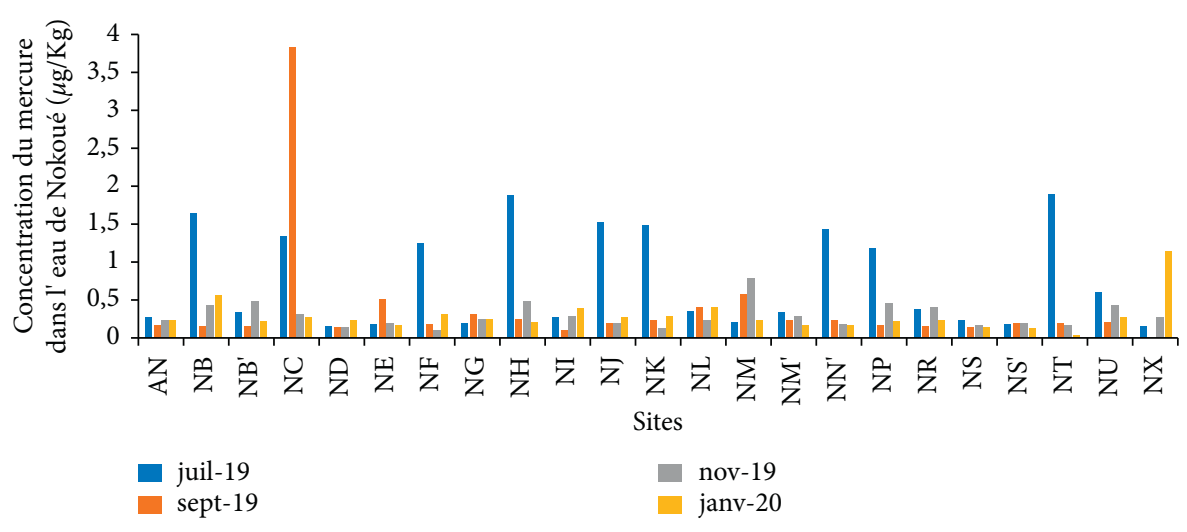

FIGURE 6: Variation in the concentration of mercury in the water of Lake Nokoué.

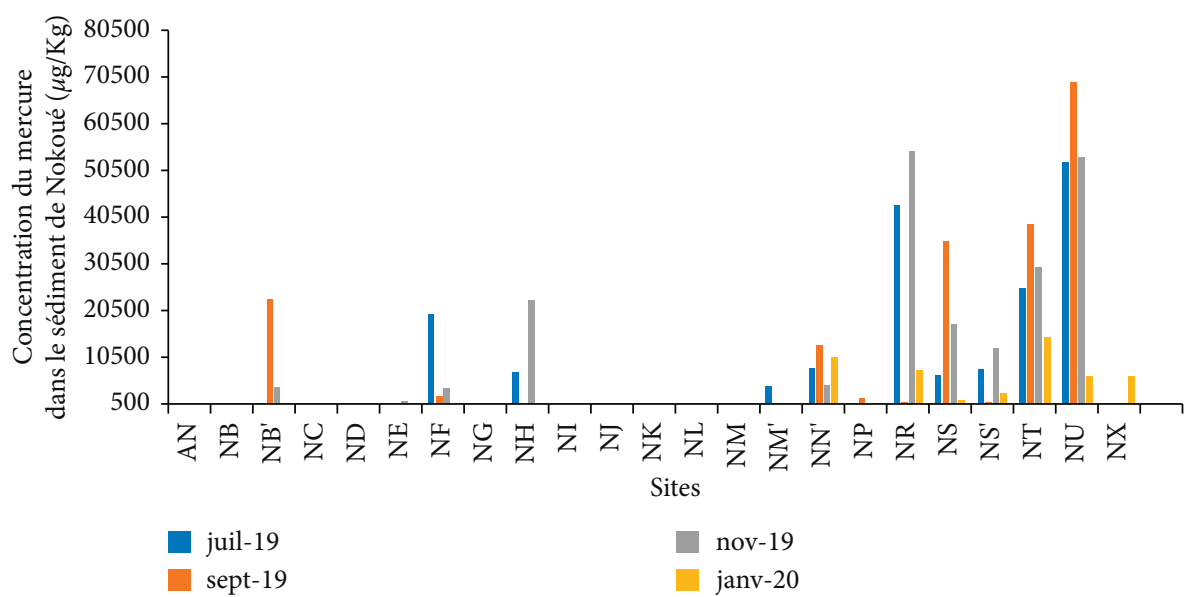

Figure 7: Variation in the content of mercury in the sediments of Lake Nokoué.

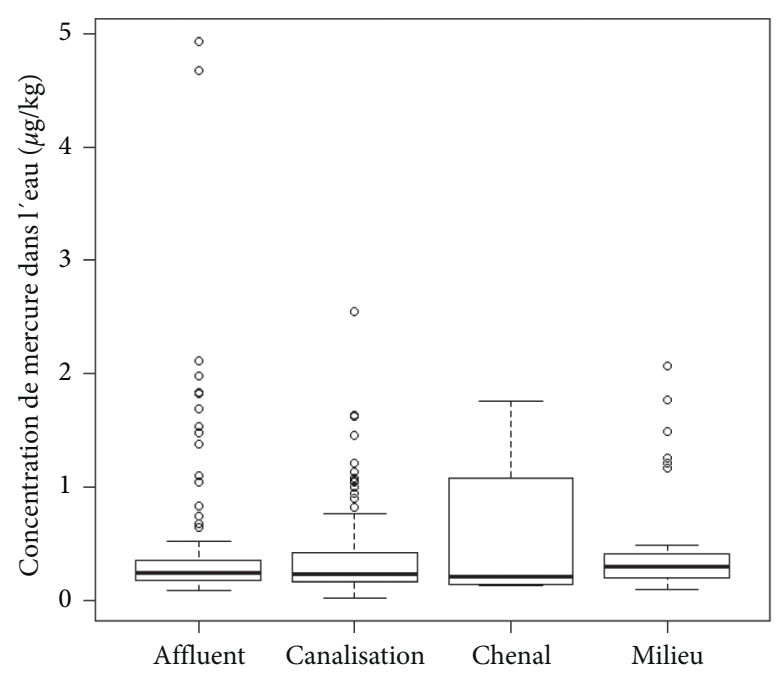

(a)

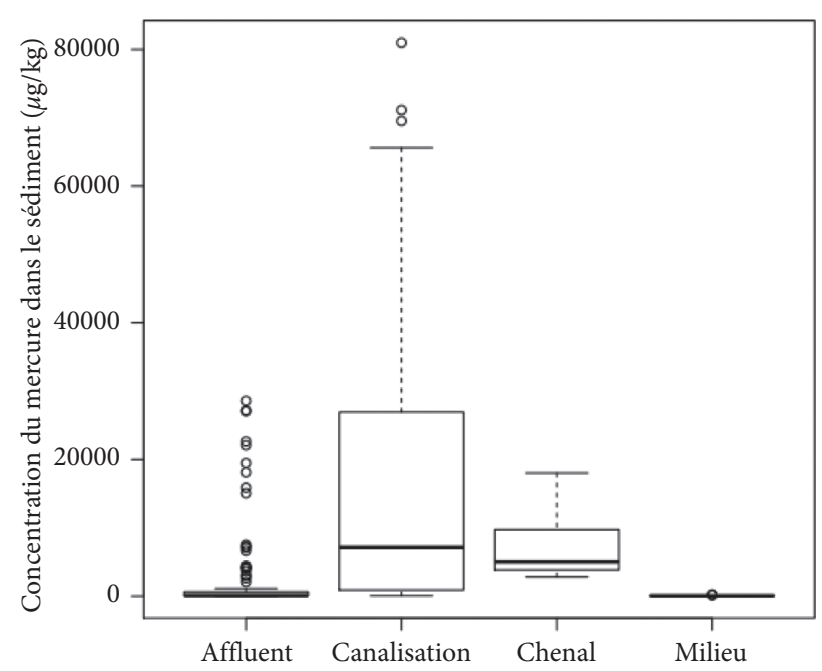

(b)

Figure 8: Global overview of the distribution of mercury in water (a) and sediment (b) by study area from July 2019 to January 2020. 
TABle 4: Analysis of variances between the parameters of Lake Nokoué water.

\begin{tabular}{lccccc}
\hline & DF & Sum sq & Mean sq & $F$ value & Pr $(>)$ \\
\hline Date & 3 & 10.23 & 3.409 & 11.627 & 0.624 \\
Zone & 3 & 0.55 & 0.183 & 1.748 & 0.6001 \\
Temp & 1 & 0.51 & 0.513 & 0.237 & 0.1873 \\
pH & 1 & 0.07 & 0.069 & 0.072 & 0.6268 \\
DCO & 1 & 0.02 & 0.021 & 0.000 & 0.7892 \\
Sal & 1 & 0.00 & 0.00 & 4.106 & 0.9985 \\
MES & 1 & 1.20 & 1.204 & 1.020 & $0.0438^{*}$ \\
Cond & 1 & 0.30 & 0.299 & 0.3133 \\
\hline
\end{tabular}

TABLE 5: ANOVA result between parameters and mercury in the sediment of Lake Nokoué.

\begin{tabular}{lccccc}
\hline & DF & Sum sq & Mean sq & $F$ value & Pr $(>)$ \\
\hline Date & 3 & $2.430 \mathrm{e}+09$ & $8.099 \mathrm{e}+08$ & 5.486 & 30.314 \\
Zone & 3 & $1.342 \mathrm{e}+10$ & $4.475 \mathrm{e}+09$ & 0.464 & $<2 \mathrm{e}^{*}-16^{* * *}$ \\
Temp & 1 & $6.843 \mathrm{e}+07$ & $6.843 \mathrm{e}+07$ & 0.017 & 0.496546 \\
pH & 1 & $2.504 \mathrm{e}+06$ & $2.504 \mathrm{e}+06$ & 0.275 & 0.896470 \\
DCO & 1 & $4.054 \mathrm{e}+06$ & $4.054 \mathrm{e}+06$ & 2.482 & 0.600671 \\
Sal & 1 & $3.664 \mathrm{e}+08$ & $3.664 \mathrm{e}+08$ & 2.208 & 0.116332 \\
MES & 1 & $3.259 \mathrm{e}+08$ & $3.259 \mathrm{e}+08$ & 0.062 & 0.138515 \\
Cond & 1 & $9.192 \mathrm{e}+06$ & $9.192 \mathrm{e}+06$ & 14.051 & 0.803141 \\
Prof-sed & 1 & $2.074 \mathrm{e}+09$ & $2.074 \mathrm{e}+09$ & & $0.000219^{* * *}$ \\
\hline
\end{tabular}

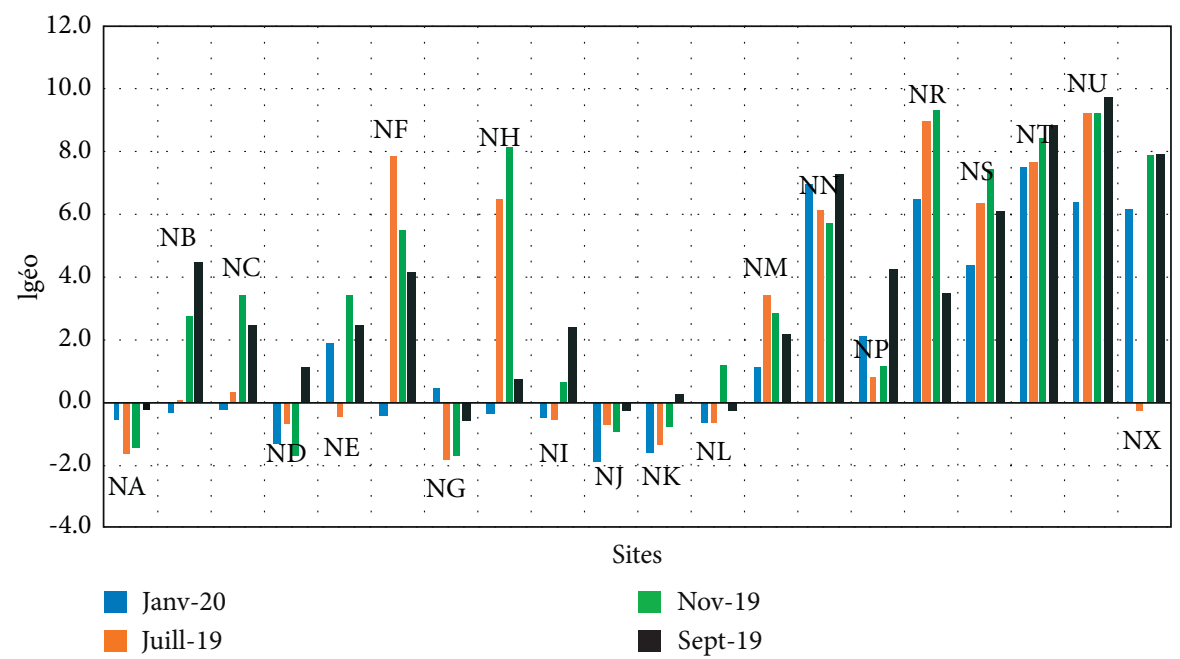

FIGURE 9: Averages of Igeo values of the sediments with respect to the seasons.

of the mercury content in the sedimentary environment. Thus, the mercury present in the sediment of Lake Nokoué depends on the seasons, the water level, and the areas sampled.

3.4. Influence of Human Activities on Mercury Pollution. From the seasonal monitoring of Lake Nokoué sediments from July 2019 to January 2020 (Figure 9), it appears that all the sites located on the body of the lake itself (NL, NK, NJ) are free of pollution (Igeo $<0)$. The sites $\left(\mathrm{NN}, \mathrm{NS}, \mathrm{NS}^{\prime}, \mathrm{NU}\right.$, NT, NX) related to the rainwater collector discharge points are extremely polluted ( $5 \leq$ Igeo) and this was observed in the four sampling campaigns. The sediments collected at the entrance to the main tributary of the Sô (NF) and the entrance to the tributary of the Porto-Novo lagoon $(\mathrm{NH})$ were found to be extremely polluted during the months of July and November 2019 and then heavily polluted at the NF site in September. In addition, the sediments collected in November and January in Ganvié (NB, NC) are slightly or moderately polluted. We deduce that the mercury quality of the lake is influenced by the domestic discharges, the temporary contribution of the Sô river and the Porto-Novo lagoon, and finally the permanent contribution of urban wastewater associated with refuse located on the shores of the lake (Figure 10). 


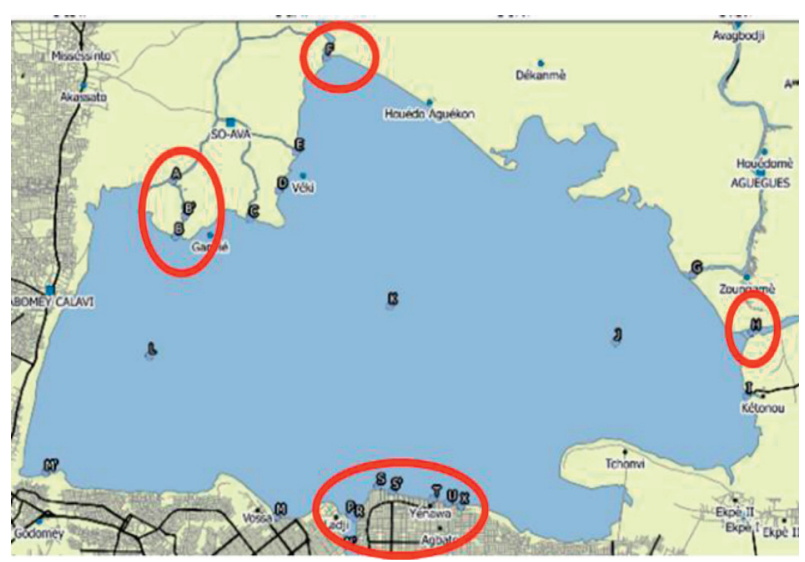

FIGURE 10: Visualization of sites with a high Igeo.

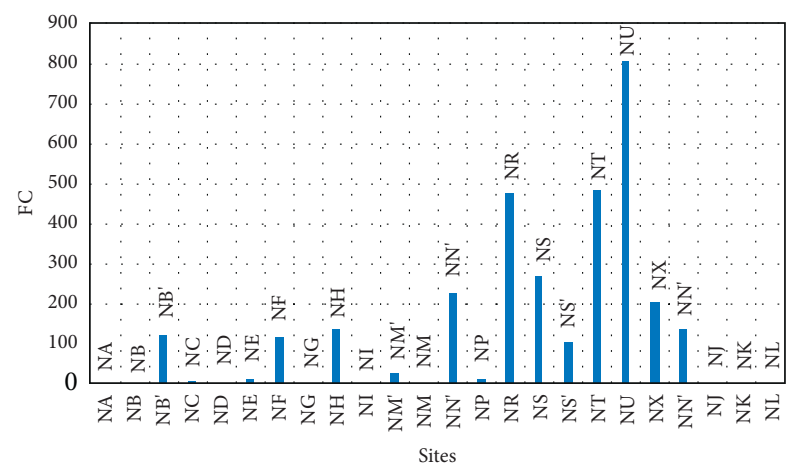

Figure 11: Average CF values for Lake Nokoué sediments 2019-2020.

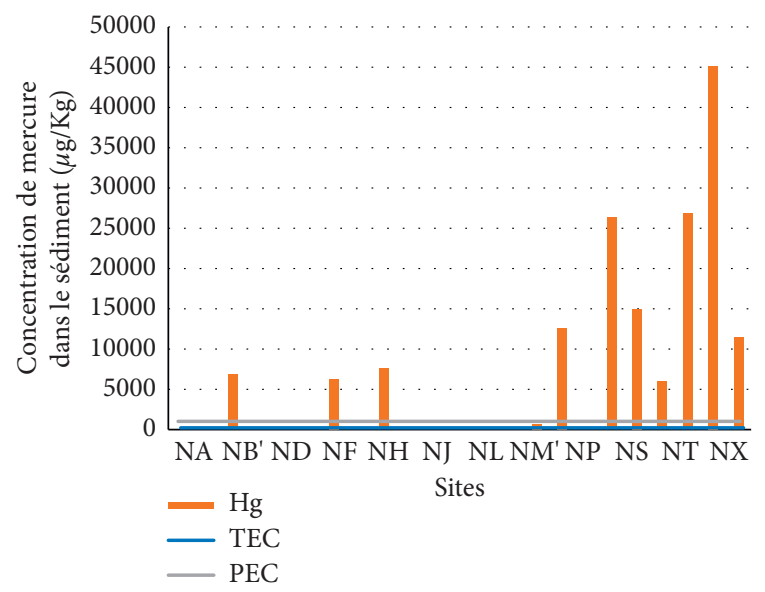

FIgURE 12: Mercury content in Nokoue sediments with regard to toxicity thresholds.

The average FC value of the sediments collected between July 2019 and January 2020 on Lake Nokoué reveals a great variability in the mercury contamination of the sediments. It appears that the NA, NG, NJ, and NK sites are not contaminated or are slightly contaminated with mercury. ND and NK sites are moderately contaminated with mercury, and NI and NM sites are significantly contaminated. In accordance with the observation made with the Igeo, the sediments in connection with the stormwater discharge sites, the refuse, the main tributary of the Sô, the tributary of Djonou, and the Porto-Novo lagoon, of which the CF exceeds all Carballeira classifications [21], are highly contaminated with mercury with the highest FC of 805.35 obtained at the NU site (located at Yénawa) (Figure 11).

$47.82 \%$ of the sites sampled on Lake Nokoué between July 2019 and January 2020 have mercury concentrations between the PEC and TEC values. This means that each of the sites presents a risk of occasional effects on benthic communities. All the remaining sites except the one at the entrance to the tributary of Djonou $\left(\mathrm{NM}^{\prime}\right)$ show mercury concentrations that exceed the PEC threshold. This means that they are likely to cause frequent harms to the benthic fauna (Figure 12).

\section{Conclusion}

This study clearly demonstrates the seasonal variation and the spatial distribution of mercury content of Lake Nokoué, both in the water body and sediment. The water body of the lake receives mercury from nonpoint sources that were seemingly linked to cotton production fields runoff and channeled through the Ouémé river, the Sô river, and the Djonou river. The high mercury content at the outlets of urban runoff drainage pipes gives additional proofs of nonpoint sources of mercury pollution of the lake. However, the high mercury concentration in the sediment at some strategic points of the lake, such as near some wild dumpsters, lake cities such as Ganvié, Zouko, and Sô-Ava, and Cotonou can be linked to point sources of pollution. The study has demonstrated that the concentration of mercury contained in the water and the sediments is influenced by the lake's water level, the rainy or dry season. Thus, the evaluation of the ecological quality of the lake sediments reveals that the sediments at the entrance to the Djonou river present risks of occasional effects to the benthic fauna and that those taken at the entrance to the Sô, the lagoon of Porto-Novo, and those of Ganvié, as well as at all the rainwater discharge sites and refuse dumps are likely to have frequent effects to the benthic fauna. In view of these findings, the stakeholders of Lake Nokoué must be sensitized for the protection of this important water body to spare the aquatic lives.

\section{Data Availability}

The data used to support the findings of this study are available within the article.

\section{Conflicts of Interest}

The authors declare that they have no conflicts of interest.

\section{References}

[1] A. N. B. Nadia, D. Hermione, H. Peace et al., "Mercury pollution and health risks: state of play in the southern basin of Benin," International Journal of Innovation and Applied Studies ISSN 2028-9324, vol. 25, no. 3, pp. 1014-1023, 2019.

[2] Y. Alassane, A. Karim, M. Daouda et al., "Sources and distribution of mercury residues in environmental and food 
matrices of the mekrou river watershed in Kèrou, Kouandé and Péhuncoin Republic of Benin," American Journal of Applied Chemistry, vol. 6, no. 2, pp. 57-63, 2018.

[3] C. Waris, M. Daouda, A. Abdoukarim et al., "Physicochemical characterization of the Porto-Novo lagoon (Southern Benin) and highlighting the pollution by mercury, copper and zinc," Journal of Applied Bioscience, vol. 43, pp. 2882-2890, 2011.

[4] E. A. P. Yehouenou, R. Adamou, P. J. Azehoun, P. A. Edorh, and T. Ahoyo, "Monitoring of heavy metals in the complex "Nokouélake-Cotonou and Porto-Novo lagoon" ecosystem during three years in the Republic of Benin." Research Journal of Chemical Sciences, vol. 3, no. 5, pp. 12-18, 2013, ISSN 2231606X.

[5] S. Bouchentouf, "Demonstration of the pollution mechanisms of water sediments in coastal areas: multidisciplinary approach," Doctoral thesis, Abou BekrBelkaid University Tlemcen, Tlemcen, Algeria, 2015.

[6] D. Fidèle, D. Flavien, A. Naéssé et al., "Physico-chemical characterization of Lake Ahémé (South Benin) and highlighting the pollution of sediments by lead, zinc and arsenic," Journal de la Societe West-Africaine de Chimie, vol. 037, pp. 36-42, 2014.

[7] H. W. Degila, N. B. Azon, J. G. Adounkpe, M. Aïna, and P. Aina Martin, "Mercury content of sarotherodon melanotheron and chrysischthys nigrodigitatus of Lake Nokoue and Porto Novo lagoon in Benin," International Journal of Biological and Chemical Sciences, vol. 14, no. 6, pp. 2322-2332, 2020.

[8] A. N. B. Nadia, H. Peace, G. Adounkpe Julien, W. Degila Hermione, and P. Aina Martin, "Direct mercury analyzer (DMA) determination of mercury distribution in the sediments of lake Nokoué in Benin Republic-West Africa," International Journal of Biologival and Chemical Science, vol. 15, no. 1, pp. 306-316, 2021.

[9] G. Müller, "Index of geoaccumulation in sediments of the Rhine river," Geology Journal, vol. 2, pp. 109-118, 1969.

[10] F. Ruiz, "Trace metals in estuarine sediments from the Southwestern Spanish Coast," Marine Pollution Bulletin, vol. 42, pp. 482-490, 2001.

[11] N. Abdelmottalib, H. Soumia, I. Nadia, Mohamed, B. Abderrahmane, and Chlaida, "Study of the metallic contamination of the surface sediments of the oued hassara after installation of the purification station (StEp) of médiouna (Casablanca, Morocco) rabat," Bulletin of the Scientific Institute, Life Sciences Section, vol. 38, pp. 1-14, 2016.

[12] S. Yao Idriss, A. D. Paul Valéry, K. K. V. Yapi, D. A. Cyrille, and Y. O. Bernard, "Evaluation de la contamination en métaux traces des sédiments du lac de kossou (Côte d'Ivoire)," Journal of Chemical Biology and Physical Science, vol. 3, pp. 217-229, 2019.

[13] B. Rubio, M. A. Nombela, and F. Vilas, "Geochemistry of major and trace elements in sediments of the Ría de vigo (NW Spain): an assessment of metal pollution," Marine Pollution Bulletin, vol. 40, pp. 968-980, 2000.

[14] D. D. Macdonald, C. G. Ingersoll, and T. A. Berger, "Development and evaluation of consensus-based sediment quality guidelines for freshwater ecosystems," Archives of Environmental Contamination and Toxicology, vol. 39, no. 1, pp. 20-31, 2000.

[15] A. Akouvi, "Dynamics of dissolved and particulate river inputs to Lake Togo: balance sheets, origins and fate, mechanisms and control factors," Docrotat thesis, University of Toulouse, Toulouse, France, 2019.
[16] M. B. Djihouessi, "Nutrient balance (N and P) for the management of eutrophication and ecosystem services in Lake Nokoué (French version: summary)," Doctoral thesis, University of Abomey-Calavi, Abomey-Calavi, Benin, 2018.

[17] A. Avumadi, "Dynamics of dissolved and particulate river inputs to Lake Togo: balance sheets, origins and fate, mechanisms and control factors," Doctoral thesis, University of Toulouse, Toulouse, France, 2019.

[18] S. Buhungu, E. Montchowui, E. Barankanira, C. Sibomana, G. Ntakimazi, and C. A. Bonou, "Caractérisation spatiotemporelle de la qualité de l'eau de la rivière kinyankonge, affluent du lac Tanganyika, Burundi," International Journal of Biological and Chemical Sciences, vol. 12, no. 1, pp. 576-595, 2018, ISSN 1991-8631 (Print) 12.

[19] H. Çadraku, F. Gashi, A. Shala, and O. Fetoshi, "Variations in the physico-chemical parameters of under groundwater of blinaja catchment, Kosovo," IFAC-PapersOnLine, vol. 49, no. 29, pp. 200-205, 2016.

[20] N. Ngaram, "Contribution to the analytical study of pollutants (in particular heavy metal type) in the waters of the Chari river during its crossing of the city of N'Djamena," Doctoral thesis, University of N'Djamena, N'Djamena, Chad, 2015.

[21] R. Jean, L. Bernard, and M. Nicole, The Water Analysis, Dunod, Paris, France, 978-2-10-054179-9, P1287, 9th edition, 2009.

[22] O. Gbago, B. Saidouba, B. Kande, and B. M. Kabirou, "Risk assessment of heavy metal pollution $(\mathrm{Hg}, \mathrm{Cd}, \mathrm{Pb}, \mathrm{Co}, \mathrm{Ni}, \mathrm{Zn})$ of water and sediments of the Konkouré river estuary (Rep. of Guinea)," Afrique Science, vol. 09, no. 3, pp. 36-44, 2013, ISSN 1813-548X.

[23] B. S. Miller, D. J. Pirie, and C. J. An, "Assessment of the contamination and toxicity of marine sediments in the Holy Loch, Scotland," Marine Pollution Bulletin, 2000.

[24] C. Lassaad and N. Mzoughi-Aguir, "Trace metals (cd, pb, hg) and total hydrocarbons in the surface sediments of the coastal fringe of the Gulf of Gabes," Bulletin de Institut National des Sciences et Techologies de Salammbô Sea, vol. 33, 2006. 